\section{Non-industrial Civil Servants}

$I_{N}$ the detailed statement as to the number of non-industrial Civil Servants in departments with staffs of more than a thousand at April 1, 1947, circulated by the Chancellor of the Exchequer in Hansard of July 1 in reply to a question in the House of Commons, the staff of the Department of Scientific and Industrial Research is given as 2,248, as against 1,502 on April 1, 1939. The Forestry Commission now employs 1,334 as against 509, the Ministry of Agriculture and Fisheries 6,233 instead of 2,591, the Ministry of Education 2,898 instead of 2,078, the Ministry of Health 5,087 as against 6,676, the Department of Agriculture, Scotland, 1,376 instead of 659, and the Department of Health, Scotland, 1,013 in place of 991 . The total is now 702,363 as against 382,709 in 1939 ; of this number 262,372 are in the Post Office. In the debate on the Post Office on the following day some reference was made to research, and the Assistant Postmaster-General stated that a house has been taken at Stone, Staffordshire, where a thousand engineers would be trained, some of whom have been at Dollis Hill. The accommodation thus released would be available for carrying out fundamental research, and by 1950 it is expected to have 150 fully qualified scientific men and engineers on such research. It is proposed to double the major engineering and scientific staff at Dollis Hill during the next fow years.

\section{Imperial Bureau of Pastures and Field Crops}

As a result of a recommendation of the 1946 Review Conference of the Imperial Agricultural Bureaux, the Imperial Bureau of Pastures and Forage Crops now becomes the Imperial Bureau of Pastures and Field Crops (director, Dr. R. O. Whyte). In its expanded form it will cover that part of the literature on the following crops not already the concern of the Bureaux of Plant Breeding and Genetics, or Soil Science : all cereals, field root-crops, pulses, groundnuts, cotton and other fibre crops grown on a field scale, sugar beet and sugar cane, in addition to the literature on grassland management and fodder production which has been the concern of the Bureau for the past seventeen years. Attention will continue to be given to those aspects of plant biological research which refer to the crops now covered, and sections will now also deal with farming systems concerned in the production of field or forage crops, and certain economic aspects of crop and fodder production.

Although the name of the Bureau has been changed to Pastures and Field Crops and a second abstracting journal (in addition to Herbage Abstracts) is to be published from 1948 onwards, it will be some time before it will be possible to claim that the extended field of research and practice is being adequately covered, or before it will be possible to reply without a little difficulty to inquiries on the new crops now added to the Bureau's responsibilities. Those concerned with these crops should send their publications and reports to the Imperial Bureau of Pastures and Field Crops, Penglais, Aberystwyth, Wales, for review in the new abstracting journal dealing with field crops. Particulars of this journal will be sent to persons interested.

\section{University of Birmingham}

THE University of Birmingham has created a chair of gastroenterology and has appointed as its first occupant Dr. T. L. Hardy. Dr. Hardy was one of the founders of the British Society of Gastro-enterologists in 1938 .

Dr. J. F. Brailsford, who is well known as a radiologist, has been appointed honorary director of radiological studies in living anatomy. Dr. Brailsford was the first radiologist to be elected Hunterian professor of the Royal College of Surgeons, and is a former president of the British Association of Radiologists.

Four members of the University have been appointed to professorial chairs overseas: Dr. F. Smith, reader in the Department of Chemistry, to the chair of chemistry in the University of Minnesota; Mr. N. M. MacElwee, lecturer in electrical engineering, to the chair of electrical engineering in University College, Christchurch, N.Z. ; Dr. T. G. Hunter, of the Chemical Engineering Department, to the chair of chemical engineering in the University of Sydney, Australia; and Dr. F. J. Llewellyn to the chair of chemistry in the University of Auckland, N.Z.

At the annual degree congregation, the Chancellor (Mr. Anthony Eden) conferred the honorary degree of doctor of science on Dr. Otto Robert Frisch, director of the Nuclear Physics Section of the Atomic Energy Research Establishment at Harwell, newly appointed Jacksonian professor of natural philosophy in the University of Cambridge. The degree of doctor of science was conferred on the following: F. A. Fox (metallurgy), J. K. N. Jones (chemistry), J. H. Partridge (metallurgy), W. T. Pell-Walpole (metallurgy), and L. F. Wiggins (chemistry).

A presentation was made to Prof. J. G. Smith, after twenty-eight years service to the University, on his retirement from the post of vice-principal. Prof. Smith is succeeded as vice-principal by Sir Norman Haworth, professor of chemistry in the University.

\section{Announcements}

IN connexion with the centenary celebrations of the Chemical Society, the University of London has conferred honorary degrees on the following: Prof. C. N. Hinshelwood, Dr. Lee's professor of chemistry in the University of Oxford (president of the Chemical Society) ; Prof. J. N. Brønsted, professor of chemistry in the University of Copenhagen; Prof. P. Karrer, professor of chemistry in the University of Zurich; Prof. L. C. Pauling, professor of chemistry in the California Institute of 'Technology.

Prof. G. H. Hardy, emeritus professor of pure mathematics in the University of Cambridge, and Dr. A. F. Blakeslee, honorary professor of botany at Smith College, Northampton, Mass., have been elected foreign associates of the Paris Academy of Sciences.

Sir Edward Appleton, Sir Alexander Fleming and Sir Arthur MacNalty have been elected honorary fellows of the Royal Society of Edinburgh.

Dr. David Heron has been elected president of the Royal Statistical Society in succession to Lord Woolton. Prof. J. H. Jones, emeritus professor of economics in the University of Leeds, has been elected honorary treasurer.

THE following appointments in the University of Sheffield have been announced : Dr. D. H. Peacock, lecturer in chemistry; C. Hulse, lecturer in fuel technology; H. D. Bush, assistant lecturer in physics; J. M. Thoday, assistant lecturer in botany and zoology (for cytogenetics); Dr. D. B. Leason, research assistant in fuel technology. Dr. R. Rado has resigned from the post of lecturer in mathematics. 